\title{
Proceeding
}

Supplementary Issue: Autumn Conferences of Sports Science. Costa Blanca Sports Science Events, 18-19 December 2020. Alicante, Spain.

\section{Power system for schoolchildren based on their genotypes}

\author{
V. I. KARPOV1 19 , M.A NIKITINA ${ }^{1}$, S.A IVANOV ${ }^{1}$, R. H BEKMANSUROV², A. V YUMASHEV ${ }^{3}$, S. N \\ SYCHANINA4
}

${ }^{1}$ K.G. Razumovsky Moscow State University of Technologies and Management, Moscow, Russian Federation

2Department of Prosthetic Dentistry, Sechenov First Moscow State Medical University, Moscow, Russian Federation

${ }^{3}$ Department of Management, Kuban State Agrarian University named after I.T. Trubilin, Krasnodar, Russian Federation

${ }^{4}$ Altai State University, Barnaul, Russia

\begin{abstract}
The article discusses a decision support system based on the clustering of genotypes and used in managing personalized nutrition for schoolchildren. The results of solving the problem for specific objects that have passed laboratory studies of gene states are presented. Modern scientific research in the field of nutrigenomics has shown that the selection of the optimal nutrition plan, taking into account genetic characteristics, increases the effectiveness of such programs by $200-300 \%$ compared with traditional approaches. This report discusses the use of soft computing (the method of clustering multidimensional objects) to determine typical clusters for managing personalized customer nutrition based on their genotypes. Keywords: Genotype; Personified nutrition; Clustering of multidimensional objects; Metrics of characteristics; Decision support system.

Cite this article as:

Karpov, V.I., Nikitina, M.A., Ivanov, S.A., Bekmansurov, R.H., Yumashev, A.V., \& Sychanina, S.N. (2021). Power system for schoolchildren based on their genotypes. Journal of Human Sport and Exercise, 16(2proc), S460-S469. doi:https://doi.org/10.14198/jhse.2021.16.Proc2.31

Corresponding author. K.G. Razumovsky Moscow State University of Technologies and Management (the First Cossack University) (Razumovsky Msutm (FCU)), 109004, St. Ground Val, 73, Moscow, Russian Federation.

E-mail: amirgendyal@yahoo.com

Abstract submitted to: Autumn Conferences of Sports Science. Costa Blanca Sports Science Events, 18-19 December 2020. Alicante, Spain.

JOURNAL OF HUMAN SPORT \& EXERCISE ISSN 1988-5202

(C) Faculty of Education. University of Alicante

doi:10.14198/jhse.2021.16.Proc2.31
\end{abstract}

S460 $2021 \mid$ Proc2 | VOLUME 16

(C) 2021 University of Alicante 


\section{INTRODUCTION}

The most important period of a person's life is school age, the time is from 7 to 17 years, the time of physical, intellectual, moral formation and active development.

In the modern world, it is the students who take over and are forced to process the increasing pressure of the information flow that affects them not only at school, but also at home. In addition to the school curriculum, many children and adolescents are additionally engaged in circles and sports sections.

For the formation and maintenance of physical and mental health and the full assimilation of the school curriculum, it is important to correctly organize the nutrition of the student (Bekmansurov et al., 2019; Panfilova et al., 2020; Ivanova, et al., 2019; Voronkova et al., 2019; Chen et al., 2019; Frolova, et al., 2019).

Many parents believe that it is enough to rely on their own intuition and common sense in the matter of feeding a student. However, it is important to know and understand the principles of good nutrition, and the rules of food hygiene, the observance of which is key in maintaining the health of the child.

Eating disorders during this period can lead not only to functional disorders and chronic diseases of the gastrointestinal tract, but also to deviations in the functioning of almost all body systems.

\section{Basic power features}

The first function is to supply the body with energy. In this sense, a person can be compared with any machine that does work but requires fuel for this. Rational nutrition provides an approximate balance of energy entering the body and spent on supporting vital processes.

The second function of nutrition is to supply the body, primarily proteins, to a lesser extent - minerals, fats and to an even lesser extent - carbohydrates (Podoprigora et al., 2019; Movchan and Yakovleva, 2019).

Finally, the third function of nutrition is to supply the body with biologically active substances necessary for the regulation of vital processes. Enzymes and most hormones - the regulators of chemical processes in the body, are synthesized by the body itself. However, some hormones the human body can synthesize only from special precursors found in food. These precursors are vitamins found in foods (Poltarykhin, 2020; Almeida et al., 2019; Prodanova et al., 2019; Melnikov, 2019; Aleksandrova et al., 2019; Filatova et al., 2019; Akhmadeev et al., 2019; Dunets et al., 2019).

More recently, there has been evidence of the existence of another (fourth) nutrition function, which is to develop immunity. With insufficient nutrition, overall immunity decreases, and the body's resistance to various infections decreases. And vice versa, good nutrition with a sufficient content of proteins, fats, vitamins and calories enhances immunity, and increases resistance to infections.

The work was carried out in accordance with the state mission of the Ministry of Education and Science "Research on the organization of nutrition and the creation of conditions for maintaining the health of students in educational institutions", project code No. 27.9928.2017 / NM. 


\section{METHODS}

Currently relevant are the directions in the development of specialized food products, as well as personalized food products and diets (based on the allelic polymorphism of individual "predisposition genes" associated with the absorption of certain food nutrients), aimed at improving the nutritional structure of the population. The indicated innovative directions for the development of science in the field of functional and personalized nutrition make it possible to solve the tasks set in the strategic program documents of the Government of the Russian Federation: "Fundamentals of the state policy in the field of healthy nutrition for the period up to 2020" and "The concept of ensuring sanitary and epidemiological welfare of the population through development functional and specialized bakery in the Russian Federation until 2020 (Bread is health). "In the Order of the Government of the Russian Federation No. 1364-r dated 06/29/2016 "Strategy for improving the quality of food products in the Russian Federation until 2030" (www.government.ru) indicates the need to create conditions for the production of new-generation food products with specified quality characteristics, including specialized, functional and enriched, organic foods (Decree of the Government of the Russian Federation).

The social essence of personalized nutrition consists in the development of a modern industry and the logistics of providing the population with food, taking into account individual and group needs. Creating a flexible food quality management system, taking into account the individual characteristics of each person, will create the prerequisites for improving labour efficiency, quality of life, and increasing life expectancy.

The theoretical support of the scientific direction "Personalized Nutrition" consists in developing a theory of the informational influence of food quality on the quality of human life processes. One of the possible tools for this effect is nutrigenomics - the science of the influence of diets on the expression of human genes. In this area, it is necessary to develop a theory for controlling the expression of favourable and unfavourable genes through nutrients (Aleksandrovich et al., 2018). A theory is also needed that describes a possible correlation of the consumer's emotional preferences and the objective needs of his body (Poltarykhin, Dibrova, 2020; Dzhavatov et al., 2018; Jafarpour et al., 2019; Ivanova et al., 2019; Bondarenko et al., 2019; Masood et al., 2019).

The methodology for the development of technical specifications for the design of an innovative consumer facility of personalized food consists in taking into account 3 groups of characteristics of the designed facility. Identification of psycho-emotional preferences of consumers is carried out by sequential refinement and detailing during the preferences surveys based on the PATTERN heuristic examination method. The method involves detailing "from general to particular". In this case, descriptors of a higher level are split into descriptors of a lower level. Detailing is carried out to obtain the final (indivisible) descriptors. The result of such a heuristic examination is a "target tree", including descriptors and their significance levels. Depending on the needs, using such a tree, various trajectories can be calculated: elements (nodes), branches (lines) and families.

Identification of the objective needs of the body according to the results of the analysis of the genome is based on a special technique. According to this technique, the genome is analysed for the presence of unfavourable gene alleles in it. If such panels are found, nutrigenomic factors are included in the project to prevent or compensate for possible nutrient deficiencies. The result of gene research should be a list of descriptors that have an inhibitory or stimulating effect on the expression of borderline gene alleles. 
Despite the wide range of possible competencies of target food products, their number is still assumed to be final. A number of technologies should be developed that allow implementing a project for the production of food products that meet the solution of standard tasks. Such products should provide the quantitative and qualitative need of the individual organism for nutrients.

Moreover, the same competencies can be assigned to food products of different food commodity groups. For example, antioxidant activity can be provided with fish, dairy, confectionery products, as well as extreme nutrition products. For a qualitative and quantitative assessment of the moisture contained in food products, various methods for its instrumental assessment have been developed and applied in practice.

One of the types of target nutrition is food with a prolonged shelf life. Caramel with a significantly reduced ability to get wet can act as such a product. To increase the shelf life of caramel, it is proposed to introduce surfactants into the caramel mass formulation. Due to the property of reducing surface tension at the interface, the surfactant in the process of glass transition of caramel mass is placed on the periphery of the product, thereby reducing its hygroscopicity.

Assessment of merchandising characteristics of bioorganic objects by nuclear magnetic resonance.

Moisture is a critical feature in the design of food products with specified consumer properties. It is often impossible to differentiate between the three states of water identified during the study (equilibrium humidity, humidity above and below equilibrium). Incorrect identification of the moisture state leads to the loss of food competencies planned during the design process.

Formulation of the problem:

Given: $\mathrm{CO}$ - the original set of multidimensional objects,

$\mathrm{CO}=\{\mathrm{Sn}\}, \mathrm{n}=1, . . \mathrm{N}$

$M p(M)$ - performance metric, $M p(i)$ - weight coefficient i specifications, $i=1, . . M$

$X(n, i)-i$ state characteristic i facility $n, n=1, . . N, i=1, . . M$

Table 1 presents the results of the analysis of the state of genes for one person. Column 4 indicates the status of the gene named in column 1. For digital processing, points $0,1,2$ is put in column 4 . When scoring $0,1,2$, it is assumed that 1 and 2 are the average and high risk of predisposition to the disease or condition, 0 means no risk to the disease or condition. In addition, fourteen genes were selected by experts to cluster the states. The metric $\mathrm{Mp}(\mathrm{M})$ is normalized (see formula 1).

$$
\sum_{i=1}^{N} M p(i)=1
$$

Source set $\mathrm{CO}$ need to be divided into multiple clusters $\mathrm{Ck}$ (see formulas 2 and 3 ):

$$
\begin{gathered}
C 0=\{C k\} k=1, . . K \\
C k=\{S z\}, z=1, . N k
\end{gathered}
$$


Any pair of clusters does not have common elements, i.e., any object can only be in one cluster (see formula 4);

$$
\forall C \in C \forall C_{1} \in C_{0}: C \cap_{C=} \varnothing
$$

where $\mathrm{Ck}$ is the set of objects of the kth class; $\mathrm{k}$ is the class number;

It is required to determine those $\mathrm{Ck}$ that maximize the $\mathrm{U}$ criterion (see formula 5):

$$
\mathrm{U}(\mathrm{K} 0)=\max \{\mathrm{U} 1(\mathrm{~K})-\mathrm{U} 2(\mathrm{~K})\} \quad \text { for } \mathrm{K}=\mathrm{N}, \mathrm{N}-1, \ldots 2
$$

where $U(K o)$ - optimal value of the clustering quality criterion;

U1(K) - class compactness with K clusters;

$\mathrm{U} 2(\mathrm{~K})$ - measure of class proximity with $\mathrm{K}$ clusters.

The measure of similarity between two objects is determined based on a potential function $\mathrm{f}(\mathrm{Si}, \mathrm{Sj})$ :

$$
\begin{gathered}
f(\operatorname{Si}, S j)=1 /(1+[2(\operatorname{Si}, S j)) ; \\
(S i, S j)=\sqrt{\left.\left.\sum_{m=1}^{N} X_{i, m}-X_{j m}\right)\right)^{2}} \\
\left.U_{1}(K)=\frac{1}{K} \sum_{k=1}^{K} 2 / k^{*}\left(N_{k}-1\right)\right)^{*} \sum_{S i C i} \sum_{S j C j} f(S i, S j) i \neq j
\end{gathered}
$$

where $\mathrm{K}$ is the number of classes at the current classification step; $\mathrm{Ck}-\mathrm{k}$ feature class; Nk - the number of objects in the class Ck; $f(\mathrm{Si}, \mathrm{Sj})$ - potential function of two objects $\mathrm{Si}$ and $\mathrm{Sj} ; \mathrm{f}(\mathrm{Si}, \mathrm{Sj})$ - distance between objects $\mathrm{Si}$ and $\mathrm{Sj}$ in the space of characteristics $\mathrm{X}$, taking into account the metric.

\begin{tabular}{|c|c|c|c|c|}
\hline Gene number & Genes & Polymorphism / mutation & wt/wt & Genotype \\
\hline 1 & CYP1A1 & $\begin{array}{c}\text { wt, } 2 A, 2 B,{ }^{*} 4: 4887 C>A \\
4889 A>G, 6235 T>C)\end{array}$ & 0 & wt/wt \\
\hline 2 & CYP1A2 & intron $1-164 C>A\left({ }^{*} 1 A>* 1 F\right)$ & 2 & $* 1 A / 1 A$ \\
\hline 3 & GSTT1 & wt, del & 0 & + \\
\hline 4 & GSTM1 & $\begin{array}{c}\text { wt, del } \\
* 4(w t)(T 341 C), 481 C>T * 5,\end{array}$ & 0 & + \\
\hline 5 & NAT2 & $\begin{array}{l}590 \mathrm{G}>A{ }^{*} 6,857 \mathrm{G}>A * 7 \mathrm{~S} 1, \mathrm{~S} 2, \\
\mathrm{~S} 3\left({ }^{*} 5,{ }^{*} 6,{ }^{*} 7\right) \text { - slow acetylators }\end{array}$ & 2 & $\mathrm{~S} 1 / \mathrm{S} 2$ \\
\hline 6 & MTHFR & $677 \mathrm{C}>\mathrm{T}$ & 0 & $\mathrm{C} / \mathrm{C}$ \\
\hline S464 & |VOLU & & (c) 202 & ity of Alicant \\
\hline
\end{tabular}

$$
\mathrm{U} 2(\mathrm{~K})=2 /(\mathrm{K}(\mathrm{K}-1))^{*} \mathrm{k} \neq 1
$$

where $\mathrm{Cp}$ - many clusters obtained as a result of solving the clustering problem,

$$
\mathrm{F}(\mathrm{Ck}, \mathrm{Cl})=1 /\left(\mathrm{Nk}^{*} \mathrm{NI}\right)^{*}
$$

Table 1. Input information for each object for processing. 


\begin{tabular}{ccccc}
\hline 7 & ADRB2 & $48 A>G, 81 C>G$ & 2 & G/G, C/G \\
8 & SR(HTR2A) & $102 \mathrm{~T}>\mathrm{C}$ & 1 & $\mathrm{~T} / \mathrm{C}$ \\
9 & PPARD & $294 \mathrm{~T}>\mathrm{C}$ & 0 & $\mathrm{~T} / \mathrm{T}$ \\
10 & NBPF3(ALPL) & rs 4654748 & 2 & $\mathrm{C} / \mathrm{C}$ \\
11 & FUT2 & rs602662 & 0 & $\mathrm{~A} / \mathrm{A}$ \\
12 & BCMO1 & rs7501331 & 0 & $\mathrm{C} / \mathrm{C}$ \\
13 & GC(D) & rs2282679 & 0 & \\
14 & APOA5 & INTERGENIC Rs12272004 & 2 & $\mathrm{C} / \mathrm{C}$ \\
\hline
\end{tabular}

Thus, optimal clustering involves maximizing the criterion (Takenaka, 2012). In essence, such a statement means that related objects are collected in each cluster, and there are significant differences between the objects of different clusters. In its class, this problem relates to soft computing problems solved by integer mathematical programming methods. To solve it, we used a complex of programs for assessing the quality of multidimensional objects (Integrated Quality Assessment).

\section{RESULT}

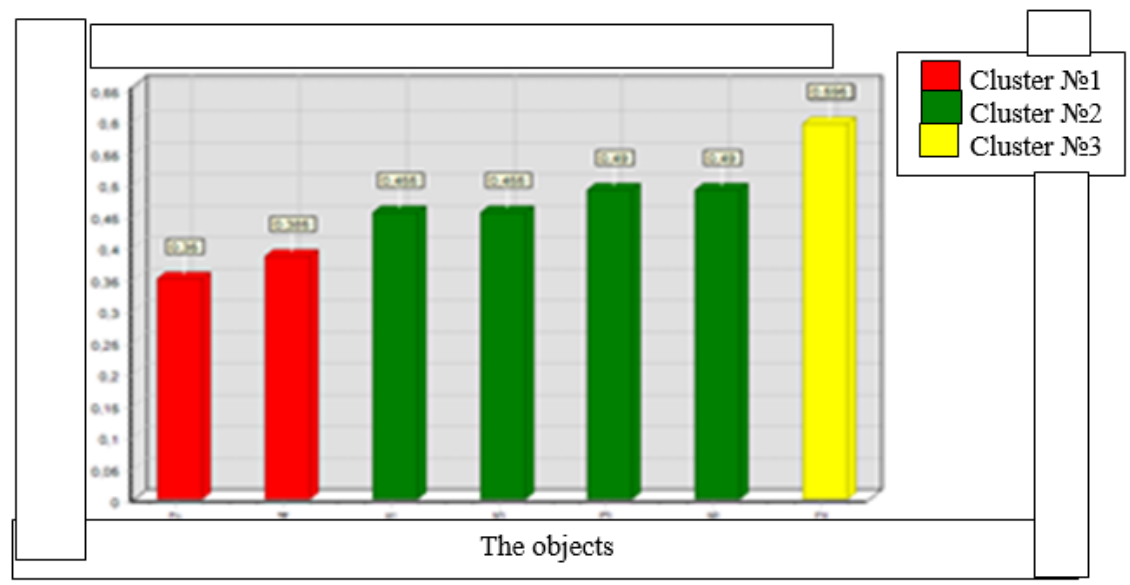

Figure 1. The results of the clustering of profiles of girls.

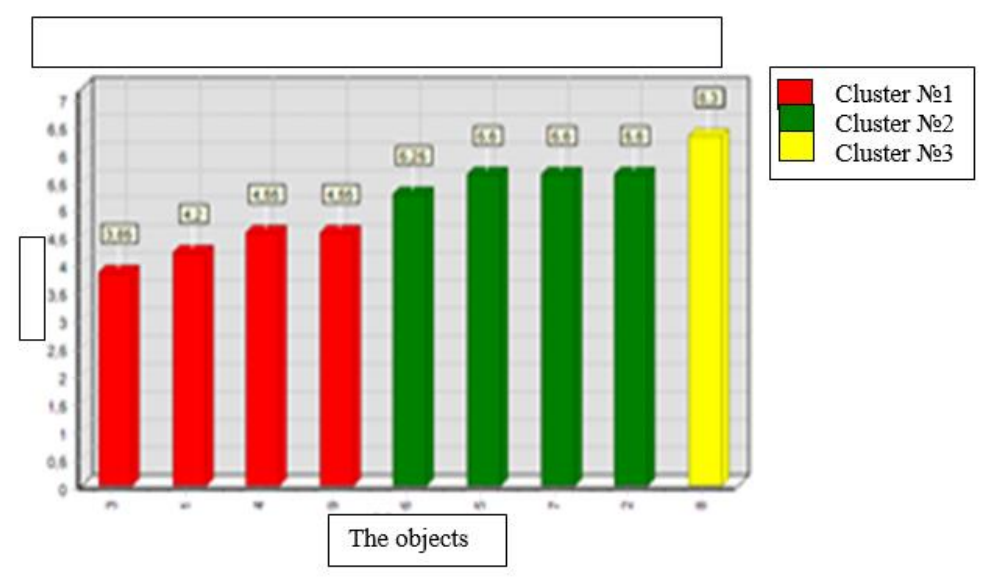

Figure 2. Clusterization results of boys' profiles. 
Figure 1 shows the results of solving the clustering problem for questionnaires for girls. Figure 2 shows the results of solving the clustering problem by questionnaires for boys. In both cases, three clusters were obtained. The interpretation and characteristics of these clusters are presented in Table 1.

Figure 3 shows the structural-functional model of the decision-making subsystem in the process of managing personalized food. Block 1 receives a stream of customers for personalized catering. At the output of this block is information about the state of the client genes, which is used in block 2 to solve the clustering problem. Next, for each cluster in block 3 , an optimal diet is developed.

Table 2. Interpretation of clusters resulting from clustering.

\begin{tabular}{|c|c|c|c|}
\hline $\begin{array}{l}\text { Diseases I } \\
\text { Conditions }\end{array}$ & Cluster №1 & Cluster №2 & Cluster №3 \\
\hline $\begin{array}{l}\text { Oxidative } \\
\text { stress }\end{array}$ & $\begin{array}{l}\text { Oxidative stress (low or } \\
\text { moderate predisposition to } \\
\text { oxidative stress) }\end{array}$ & $\begin{array}{l}\text { Oxidative stress (medium or } \\
\text { high susceptibility to } \\
\text { oxidative stress) }\end{array}$ & Oxidative stress high \\
\hline Antioxidant & Antioxidant status high & Antioxidant status medium & Low antioxidant status \\
\hline Obesity & $\begin{array}{l}\text { No (not predisposed to } \\
\text { obesity) }\end{array}$ & $\begin{array}{l}\text { No or there (no } \\
\text { predisposition or moderate } \\
\text { predisposition to obesity) }\end{array}$ & $\begin{array}{l}\text { there is (revealed an } \\
\text { average predisposition to } \\
\text { obesity) }\end{array}$ \\
\hline $\begin{array}{l}\text { Nutrition / Diet } \\
\text { Enriched }\end{array}$ & Balanced diet & $\begin{array}{l}\text { Low Carbohydrate, Vitamin } \\
\text { Enriched Nutrition }\end{array}$ & $\begin{array}{l}\text { Low Carbohydrate, High } \\
\text { Vitamin Eating }\end{array}$ \\
\hline
\end{tabular}

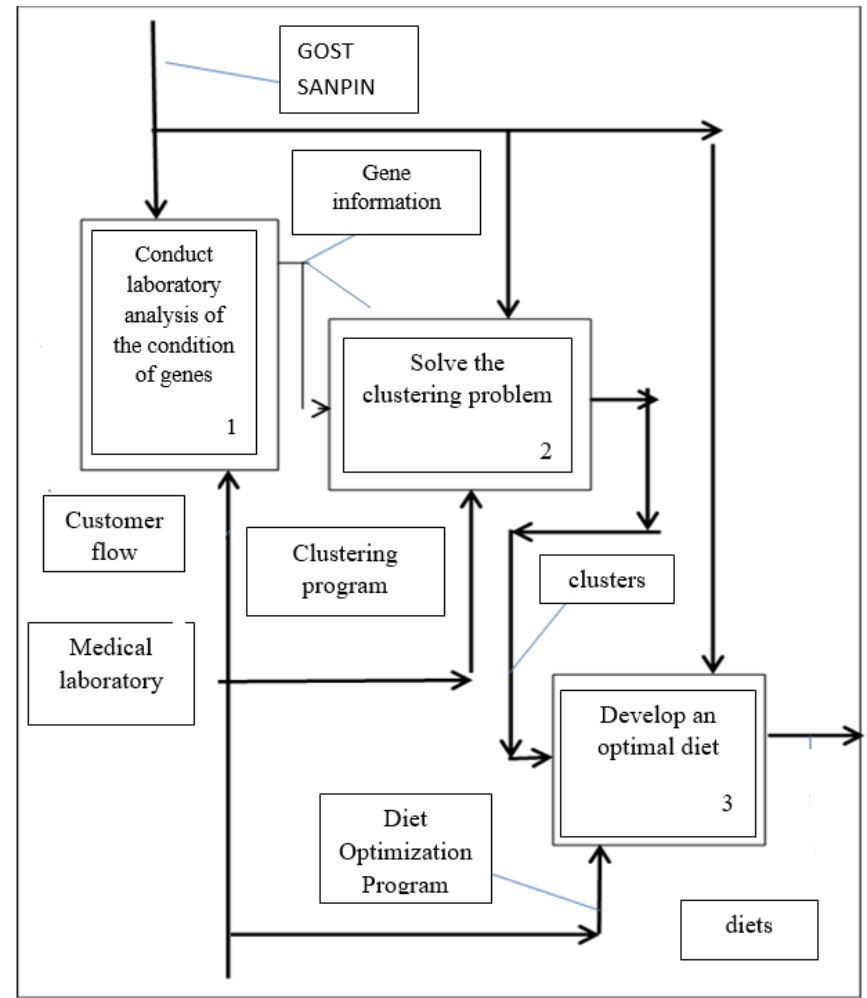

Figure 3. Structural-functional model of the decision-making subsystem in managing personalized nutrition for schoolchildren. 


\section{CONCLUSION}

This article discusses the statement of the problem of clustering information about the state of customer genes for their personalized nutrition. A program is proposed to solve this problem. The result of solving the clustering problem for real customers who have undergone special medical analyses of the conditions of 14 genes is presented. A methodology has been developed for consumer clustering within a given social group based on threats to their disease state, determined according to the genome. The technique allows to identify clusters with different levels of resistance to hereditary diseases and disease states. A structural and functional model of the decision-making system is developed for managing personalized nutrition for schoolchildren.

\section{REFERENCES}

Aleksandrovich L.V., Pavlovna K.P., Kimovich T.I., Sergeevich T.D. (2018). Development of smart well units for multilayer reservoirs operated with the system of simultanous-seprate exploitation. Journal of Applied Engineering Science, 16(4), 561-564. https://doi.org/10.5937/jaes16-17676

Almeida, M. V. D. A., Silva, E. M. D., Gomes, N. Â., Nunes, L. A. O., \& Curi, W. F. (2019). Environmental quality of campina grande landfill based on technical and operational aspects. [Qualidade ambiental do aterro sanitário de campina grande com base em aspectos técnicos e operacionais] Periodico Tche Quimica, 16(32), 77-86.

Akhmadeev, R., Morozova, T., Voronkova, O., \& Sitnov, A. (2019). Targets determination model for vat risks mitigation at B2B marketplaces. Entrepreneurship and Sustainability Issues, 7(2), 1197-1216. https://doi.org/10.9770/jesi.2019.7.2(28)

Aleksandrova, T.N., Nikolaeva, N.V., Potemkin, V.A. (2019). Beneficiation of carbonaceous rocks: New methods and materials. Innovation-Based Development of the Mineral Resources Sector: Challenges and Prospects - 11th conference of the Russian-German Raw Materials, 2018, pp. 391398.

Bekmansurov, R. H., Kovalenko, K. E., Utkina, K. M., Novikova, Y. A., Zatsarinnaya, E. I., \& Rozentsvaig, A. I. (2019). State support for persons with disabilities in the field of entrepreneurship. Journal of Entrepreneurship Education, 22(S2), 1-9.

Bondarenko, A.V., Islamov, S.R. \& Mardashov, D.V. (2019). Features of oil well killing in abnormal carbonate reservoirs operating conditions. 15th Conference and Exhibition Engineering and Mining Geophysics 2019. European Association of Geoscientists and Engineers (ISBN: 978946282282-5), pp. 629-633. https://doi.org/10.3997/2214-4609.201901759

Chen, T., Babanin, A., Al-Qāsim, M. A., Chapron, B., Chen, J., \& Md, S. H. S. H. (2019). Prototype of web-based daily work report management system using smart pens. Journal of Applied Engineering Science, 17(3), 280-283. https://doi.org/10.5937/jaes17-18602

Comprehensive quality assessment and classification of multidimensional objects. Certificate of official registration of computer programs No. 2006613936 of the Russian Federation; Myshenkov K.S., Karpov V.I., Getman V.V. - No. 2006613704; Application 11/02/2006; Zaregistr. 11/16/2006

Decree of the Government of the Russian Federation No. 1364-r dated 06/29/2016 "Strategy for improving the quality of food products in the Russian Federation until 2030" (www.government.ru).

Dzhavatov, D. K., Sverdlikova, E. A., Sokolov, M. S., Avdeeva, O. A., \& Yavkin, G. P. (2018). The influence of innovation on social and economic development of the russian regions. European Research Studies Journal, 21(Special Issue 2), 767-776

Dunets, A. N.; Vakhrushev, I. B.; Sukhova, M. G.; Sokolov, M. S.; Utkina, K. M.; Shichiyakh, R. A. (2019). Selection of strategic priorities for sustainable development of tourism in a mountain region: 
concentration of tourist infrastructure or nature-oriented tourism, Entrepreneurship and Sustainability Issues 7(2): 1217-1229. https://doi.org/10.9770/jesi.2019.7.2(29)

Filatova, I., Shabalov, M., \& Nikolaichuk, L. (2019). Regulation methods in natural monopoly markets case of russian gas network companies. International Journal of Engineering Research and Technology, 12(5), 624-630.

Frolova, I., Voronkova, O., Alekhina, N., Kovaleva, I., Prodanova, N., \& Kashirskaya, L. (2019). Corruption as an obstacle to sustainable development: A regional example. Entrepreneurship and Sustainability Issues, 7(1), 674-689. https://doi.org/10.9770/jesi.2019.7.1(48)

Ivanova, V., Poltarykhin, A., Szromnik, A., \& Anichkina, O. (2019). Economic policy for country's digitalization: A case study. Entrepreneurship and Sustainability Issues, 7(1), 649-661. https://doi.org/10.9770/jesi.2019.7.1(46)

Ivanova, T. S., Malarev, V. I., Kopteva, A. V., \& Koptev, V. Y. (2019). Development of a power transformer residual life diagnostic system based on fuzzy logic methods. Paper presented at the Journal of Physics: Conference Series, 1353(1). https://doi.org/10.1088/1742-6596/1353/1/012099

Jafarpour, H., Moghadasi, J., Khormali, A., Petrakov, D. G., \& Ashena, R. (2019). Increasing the stimulation efficiency of heterogeneous carbonate reservoirs by developing a multi-bached acid system. Journal of Petroleum Science and Engineering, 172, 50-59. https://doi.org/10.1016/i.petrol.2018.09.034

Kim YJ, Huh I, Kim JY, Park S, Ryu SH, Kim KB, Kim S, Park T, Kwon O. (2017). Integration of Traditional and Metabolomics Biomarkers Identifies Prognostic Metabolites for Predicting Responsiveness to Nutritional Intervention against Oxidative Stress and Inflammation. - Nutrients. 2017 Mar 4; 9(3). pii: E233. https://doi.org/10.3390/nu9030233

Masood, O.; Tvaronavičienè, M.; Javaria, K. (2019). Impact of oil prices on stock return: evidence from G7 countries, Insights into Regional Development 1(2): 129-137. https://doi.org/10.9770/ird.2019.1.2(4)

Melnikov, A.B., Mikhailushkin, P.V., Poltarykhin, A.L., Dibrova, Z.N. (2019) Economic aspects of the resolution of the issue of food security: A case study. Entrepreneurship and Sustainability Issues, Year 2019. Volume 7 Nomber 1. Page 595-602. https://doi.org/10.9770/jesi.2019.7.1(41)

Movchan, I. B., \& Yakovleva, A. A. (2019). Refined assessment of seismic microzonation with a priori data optimisation. Journal of Mining Institute, 236, 133-141. https://doi.org/10.31897/pmi.2019.2.133

Nielsen D.E, Shih S, El-Sohemy A.// Perceptions of genetic testing for personalized nutrition: a randomized trial of DNA-based dietary advice. - J Nutrigenet Nutrigenomics. 2014; 7(2): 94-104. https://doi.org/10.1159/000365508

Panfilova E., Dzenzeliuk N., Domnina O., Morgunova N., Zatsarinnaya E. (2020) The impact of cost allocation on key decisions of supply chain participants. International Journal of Supply Chain Management. 2020. Volume 9, Issue 1, Pages 552-558.

Podoprigora, D. G., Korobov, G. Y., \& Bondarenko, A. V. (2019). Acid stimulation technology for wells drilled the low-permeable high-temperature terrigenous reservoirs with high carbonate content. International Journal of Civil Engineering and Technology, 10(1), 2680-2696.

Poltarykhin, A., Dibrova Z., Kovaleva I., Vasyutkina L., Potekhina E. and Zinisha O. (2020) World experience in the application of antitrust regulation and compliance system. Entrepreneurship and Sustainability Issues, Year 2020. Volume 7 Number 3. Page 2313-2325. https://doi.org/10.9770/jesi.2020.7.3(57)

Poltarykhin, A., Ivanova, V.N., Sidorenko Y. (2020) Strategic approaches to management in the field of solid municipal waste management. Talent Development and Excellence 12 (Speciallssue3), c. 700709 . 
Prodanova, N., Trofimova, L., Pozdeeva, S., Melekhina, T., Rustanov, A., \& Guryanova, I. (2019). Perspective of developing software for financial reporting under IFRS in the system of national governance. Journal of Advanced Research in Dynamical and Control Systems, 11 (8 Special Issue), 406-410.

Sidorenko M.Yu. Personalized food. - M .: DeLi Plus, 2016 .-- 192 p.

Sidorenko M.Yu., Stroykova A.A. The methodology for designing personalized diets based on the mechanism of psychological motivation of the consumer, Commodity expert. food products, 2012, No. 10. - p. 15-19.

Takenaka A., Nakamura S., Mitsunaga F., Inoue-Murayama M., Udono T., Suryobroto B. Human-specific SNP in obesity genes, adrenergic receptor beta2 (ADRB2), Beta3 (ADRB3), and PPAR y2 (PPARG), during primate evolution. - PLoS One. 2012; 7(8): e43461. https://doi.org/10.1371/journal.pone.0043461

Voronkova, O., Nikishkin, V., Frolova, I., Matveeva, E., Murzagalina, G., \& Kalykova, E. (2019). Importance of the process of teaching the basics of social entrepreneurship for the sustainable development of society. Entrepreneurship and Sustainability Issues, 7(2), 1048-1058. https://doi.org/10.9770/jesi.2019.7.2(18)

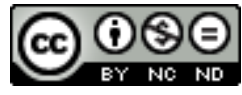

This work is licensed under a Attribution-NonCommercial-NoDerivatives 4.0 International (CC BY-NC-ND 4.0). 